\title{
Research on the Enterprise Marketing Strategy Analysis Based on Modern Consumer Behavior
}

\author{
Danlin $\mathrm{Li}^{1, \mathrm{a}}$ \\ ${ }^{1}$ Jilin Business And Technology College, Jilin, China \\ a6205918@qq.com
}

Keywords: Consumer Behavior, Marketing, Strategy Research

\begin{abstract}
As the development of socialist market economy, the consumer demand of people is increasingly strongly. But at this stage, as the market continues to improve, people's consumer psychology and consumer motivation has a broader and constantly changing. Thus, in the process, how to do the right marketing strategy analysis and meet customers' demand are very significant for self-realization of benefits.
\end{abstract}

\section{Introduction}

Economic restructuring and promote the development of consumer behavior continues to develop and update, how to ensure that the enterprises to promote the process of marketing strategy to gain more business interests are business owners need to carefully consider the proposition. To achieve this goal, we need to research on consumer behavior. In this paper we analysis the importance of consumer behavior and business marketing strategy.

\section{The Modern Consumer Behavior Theory}

Overview. Modern theory of consumer behavior is to produce short and the future development of the law of the phenomenon of consumer behavior and consumer behavior analysis. The object of analysis for the modern consumer is no longer separate individual consumer, but the consumer, consumers, combined with consumer goods three. During the theory of consumer behavior analysis at the same time, the need to meet the development stage of the regularity of the times, maintain the perspective of development, the development of the law to deal with the changing consumer behavior. At this stage, the modern consumer theory in the process, people can better meet customer demand in the market, the degree of preference for people of different consumer goods, good business marketing strategy analysis to reasonable production and sales. However, the theoretical analysis of modern consumer behavior in the process, it is also recognized that the presence of the consumer behavior analysis is more one-sided, incomplete understanding of the process, understand the object does not reflect the overall market is insufficient, needs further improvement.

Characteristics of the Modern Consumer Behavior Theory. The main feature of the modern consumer behavior changes rapidly, the stability is weak and diversified, multi-level features. With the improvement of people's living standards, people buy demand for consumer goods has undergone great changes: embodied in the purchase daily necessities mainly to the gradual housing, cars and other luxury goods purchasing needs turning. In modern society, the process of conducting consumer spending reflected the characteristics of the purchase of consumer goods, according to personal preferences more to buy, compared with the seller owned the initiative, the initiative has more advantage that later in the process of buying the purpose will be more clear. On the one hand, consumers buy products still tend to buy inexpensive, but quality requirements significantly higher than in the past. And, at the same time consumption, more consumers prefer the spirit of consumer products. On the other hand, the modern consumer behavior pattern has undergone great changes, and guide consumer behavior theory to make a change. With the development of the Internet and other network technologies, online shopping, and other derivative consumption patterns emerged, consumer spending and attitudes treat changes continue to occur. People in Taobao, Jingdong, Ali Baba and other software platform for shopping are constantly looking for their favorite products. So, 
changes in consumption patterns, corporate marketing business model is constantly changing and updated in order to better meet the various people numerous and diverse consumer demand.

The Necessity of Studying the Modern Consumer Behavior Theory. Consumer demand for modern consumer is changing, and the corporate marketing strategy, if what you want is just a passive market can not meet the necessary requirement for economic prosperity and development, in terms of operating profit companies can not achieve the desired effect. Therefore, enterprises in the process of selling goods and products, the need for corporate marketing strategy rational planning and in order to achieve the actual operation of enterprises to meet the expectations of the results. The company's marketing strategy is how to set? This theory of consumer behavior and characteristics of the modern consumer is closely linked. Enterprises, businesses only to consumer behavior, consumer psychology of the situation in the chest, and to develop the market to meet consumer objects of consumer goods to the real implementation of corporate marketing strategy for the development of enterprises has brought more economic benefit. Therefore, in order to achieve a win-win for businesses and consumers, companies need to theory of modern consumer behavior carefully try to figure out a better understanding of droplet dynamics of consumer spending behavior.

\section{Marketing Strategy of Business}

Increase Brand Strategy. In modern society, people are more focus on product quality, brand to more consumers' excellent quality assurance. And during the process of marketing of goods or services, the first step to ensure the sale of the cards of the same stable, Accurate business marketing is to carry out the external packaging, set the direction of the core business, started business process brand strategy. In the course of business at this stage of the business, the more profitable is the big brand shopping malls, small shops and wholesale and retail operating profit compared difficult. In contrast, small businesses exposed the lack of awareness of the brand in the course of business, but at a low price for the overall business development direction, towards their own difficult step in the marketing industry. Therefore, by the big brands and small shops than you can reflect the business in the course of business can learn marketing strategies: by enterprises in the marketing process established brand strategic objectives, high-quality products, the company's Features as advertised by the slogan of the brand, publicity, well-known to the public. Therefore, the company's marketing is not just the price war, but also reflects the unique nature of the competitive enterprise products. By improving the business brand strategy, enterprises can promote better achieve marketing goals, meet consumer psychology.

Guide Consumers to Consume. Consumers are likely to be present blind herd of consumer psychology in the process of consumption. The reason businesses need to do is to guide consumers to the consumer in the marketing process. In the process of enterprise marketing, the need for consumer products were clear and reasonable position, such as functional products, landscaping products and so on, for each product as well as the conditions of the function, people have to adapt to a reasonable description. Preparations before this marketing acted the role of the consumer guide, were to lead to consumers prior to the consumer choice, to ensure that the process of conducting consumer spending in more explicit direction of consumption.

Implement the Price Policy. Consumption is a consumer and the consumer goods sold or services salesman transactions between the two sides. In order to achieve the best results in winning this transaction achieve win concessions on both sides need to work together. Value consumers seeking the highest product and businesses will want their products to maximize the economic profit. In order to achieve a balance between the two, operators need to specify the correct price strategy, based on supply and demand and consumer markets consumer behavior and consumer psychology, and reasonable pricing. While the people's living standards improved, rising incomes, but the pursuit of the lowest cost is still the most optimal product consumer psychology. Thus, in the course of business, to have a long-term marketing strategy at the right time, appropriate to raise or lower prices of commodities, the market needs to find a balance, get more consumers. 


\section{Recommendation for Business Marketing Strategy}

Meet Consumer Demand at Maximum Extent. There is a saying: the customer is the king. How to make their business a leading position in the market? The first condition is to meet consumer demand to the maximum extent. Not only did it in terms of price and quality of consumer goods consumer satisfaction, consumer spending in the process you want to provide good consumer advice, to answer consumer services such as consumers and allow them to feel the increase in satisfaction at the same time desire to buy these products, increasing consumer demand for the purchase of consumer goods.

Make the Consumer After-Sale Protection Work Well. Consumer behavior is not only a satisfactory level in the buying process, and more importantly, in recognition of the extent of the use of consumer products sectors after the purchase of consumer goods. Therefore, companies should research in the sale, after-sales feedback, and after-sales service all aspects of good and reasonable marketing strategy planning, a good understanding of all aspects of consumer spending during the praise of this enterprise. In order to do business properly marketing strategy, companies need to fully grasp the situation better consumer information act, to do the work of after-sale protection of consumers.

Cater Time Value Trend. The scientific and rational influence consumption is small, but reasonable consumer society as a whole is the rational use of social resources, energy and an important manifestation of the value of a variety of products. Therefore, enterprises in the development of marketing strategy at the same time to do business with a conscience, producing high-quality products, but also reasonable price, not to deceive consumers. At the same time to develop in line with the objectives of the future development of the society, to develop the right marketing strategy to enable enterprises to design products more in line with the trend of the times, more to meet consumer needs.

\section{Conclusion}

In modern society, corporate marketing strategy is an important strategy to meet the reasonable method of marketing. In business marketing process, if ignored consumer demand, not only can not meet consumer demand, but also make the whole product markets in chaotic situation, the trend is not conducive to the overall development of the economy. Therefore, companies need to combine marketing strategies and consumer behavior to achieve win-win results and increase social benefits.

\section{References}

[1] Wang Yubin: Financial Economics, Vol. 6 (2015) No 2, p.112-113

[2] Sun Siwei, Wang Hanjie: Enterprise Reform and Principles, Vol. 16 (2014) No 27, p.106 